\title{
Interpreting Cultures: Literature, Religion, and the Human Sciences
}

\author{
Jonathan Hart
}




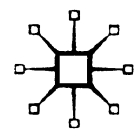

INTERPRETING CULTURES

C) Jonathan Hart, 2006.

Softcover reprint of the hardcover 1st edition 2006 978-1-4039-7128-9

All rights reserved. No part of this book may be used or reproduced in any manner whatsoever without written permission except in the case of brief quotations embodied in critical articles or reviews.

First published in 2006 by

PALGRAVE MACMILLAN ${ }^{\mathrm{TM}}$

175 Fifth Avenue, New York, N.Y. 10010 and

Houndmills, Basingstoke, Hampshire, England RG21 6XS

Companies and representatives throughout the world.

PALGRAVE MACMILLAN is the global academic imprint of the Palgrave Macmillan division of St. Martin's Press, LLC and of Palgrave Macmillan Ltd. Macmillan ${ }^{\circledR}$ is a registered trademark in the United States, United Kingdom and other countries. Palgrave is a registered trademark in the European Union and other countries.

ISBN 978-1-349-73591-4 ISBN 978-1-137-11665-9 (eBook)

DOI 10.1007/978-1-137-11665-9

Library of Congress Cataloging-in-Publication Data

Hart, Jonathan Locke, 1956-

Interpreting cultures : literature, religion, and the human sciences / Jonathan Hart.

p. $\mathrm{cm}$.

Includes bibliographical references and index.

1. Literature-Philosophy. 2. Literature-History and criticism.

3. Literature and history. 4. Civilization. I. Title.

PN49.H343 2006

$801-\mathrm{dc} 22$

2005045624

A catalogue record for this book is available from the British Library.

Design by Newgen Imaging Systems (P) Ltd., Chennai, India.

First edition: May 2006

109876654321

Transferred to digital printing in 2008 . 


\section{Part 1 Recognitions}

Chapter One Discovering Recognition

1.1 Gaining Recognition or Discovery across Faculties

1.2 Recognizing the Background: Embarrassment, Mythology, and Ideology 23

1.3 Biblical Instances

1.4 Classical Examples: Epic, Tragedy, Comedy 33

1.5 Some Philosophical Instances

1.6 History: Exempla from Crossing Cultures 54

1.7 Psychology and Some Psychoanalytical Examples

1.8 Tentative Conclusions

\section{Part 2 Readings: History and Poetics}

Chapter Two History and Empire

2.1 Texts and First Contacts $\quad 75$

2.2 Narratives of the New World 77

2.3 English Colonial Hopes 79

2.4 Permanent Colonies 80

2.5 British and French America:

Consolidation and Contestation 81

2.6 British America: From Triumph to

Loss and Continued Tensions 83

2.7 Canada as and at a Crossroads 86 
Chapter Three Recognizing Canadian

Women and Women in Canada 89

3.1 Seeing Double $\quad 89$

3.2 Elizabeth Bishop 93

3.3 Native Poets and Poets and Natives 95

3.4 African Canadian Writers and the Double Bind/Doubly Blind $\quad 98$

3.5 More Dualities

Chapter Four Writing and History: T.E. Lawrence and Bernard and Charlotte Shaw 106

4.1 A Writer and Not 109

4.2 From the Shaws' Lawrence to the Posthumous Film and Back Again 117

4.3 The Shavian Belief in Lawrence 122

4.4 The Sack of a Hero 127

4.5 The Recognition of Charlotte Shaw 131

4.6 The Wound 134

4.7 Publish and Perish 135

4.8 Seeing among the Pillars or a Genius of Publicity

Chapter Five Poiēma, Theoria, and Tekhnē

5.1 Poetics of Communication 143

5.2 Theory 144

5.3 Poetry and Poets 147

5.4 Technology 149

5.5 Poetry Then and Now 152

$\begin{array}{lll}\text { Chapter Six } & \text { Poetry and Mythology: Coda }\end{array}$

6.1 Mythos 158

6.2 Mythology and Ideology 159

6.3 Some Possibilities for Poetry 161

6.4 A Poetry that Moves, or through the Vanishing Point 163

\section{Part 3 Readings: Writers, Images, and Poets}

Chapter Seven Creating the Word: Northrop

Frye and Writing

7.1 Finding a Context 


\section{Contents}

7.2 Looking for Self-Expression $\quad 169$

7.3 The Paradoxical Visionary 176

7.4 Critic and Writer 179

7.5 The Road Not Taken 181

Chapter Eight Seeing Inside Willy Loman's Head:

The Tragedy of the Commoner on Film 185

8.1 A Kind of Tragedy 186

8.2 The End of the Play and the End of Tragedy 187

8.3 Requiem 190

8.4 Can Films Get Inside of This Salesman's Head?

Chapter Nine Placing Ireland: Some Lyric Poets 194

9.1 W.B. Yeats 196

9.2 Seamus Heaney 204

9.3 Paul Muldoon and Mary O’Malley 206

9.4 Some Further Meditations 208

Chapter Ten Being Novel, Almost and Not 210

10.1 Some Fictions 211

10.2 Traveling Mimesis or to See or Not to See 214

10.3 Expanding and Moving Fictions 219

10.4 Recognition and Misrecognition
Once More

$\begin{array}{ll}\text { Conclusion } & 223\end{array}$

Notes 239

$\begin{array}{ll}\text { Index } & 317\end{array}$ 
For Julia Jackman Marshall Hart

De Guiche-C'est un fou,-mais c'est un fou savant. Cyrano-Non, je n'imitai rien de ce qu'on fit avant!

Edmond Rostand, Cyrano de Bergerac, Acte III, Scène XI, 1633-34 


\section{P R E F A C E A N D}

\section{A C K N O W L E D G M E N T S}

It often takes me a great deal more time to write a book than I would like. This is probably a fairly widespread phenomenon. In this labyrinth, I have tried to wind a thread from introduction to conclusion without the journey being too full of rectilinear hedgerows or too much a garden of forked paths.

Whereas the book seeks some unity through interpretation of culture(s), especially but not exclusively in terms of recognition, and with regard to literature, religion, and the human sciences, it is not something straightforward in the linear movement of a single-minded argument. It is meant to be suggestive and heuristic, a tentative book with a series of linked (but not locked) hypotheses and possibilities. This is the possible realm of the actual world and its fictions, theory as a way of seeing, not as a one-eyed vision of the world. This is not a system to put the lock on my readers. Here is one person seeing and one person interpreting culture(s) for a reader with a different pair of eyes. I hope we will meet in some enabling and helpful space of intersubjectivity. We are moving objects in a paradox of objectivity even as we are the subject of our subject.

Different readers will garner different experiences from this book. As usual, I hope to reach an array of students, colleagues, and members of the general public. This is always a fine line to walk, perhaps a trapeze or high wire as much as a thread, but I think that books are as much of an engagement as a conversation or a seminar, so I am always pleased if each reader takes something from my books. Books teach. Teaching is an interaction, an engagement, perhaps a kind of love letter. So I am trying once more, recognizing the improbable and probable shortcomings along the way, to write something that is as inclusive as possible. All of 
us are subject to the shadows of Plato's cave or, with Ariadne in the labyrinth, find it difficult to see as well as we would like. Insight is hard to find. This whole book is an "essay" to discuss topics vital to people outside as well as inside the university: those with an interest that allows a break from something else, or those starting intensive study and those who, as expert as they are, might find a few new tatters to turn to threads of their own. For all these readers, my hope is that they spin their own silk. Virgil points to paradise, but cannot proceed there though Dante can, and it may be, in this purgatory of culture and its signs, that all I can do is point to Virgil and Dante. Along the way, I can also show other figures that swim around Beatrice and all of us. Rodin placed the thinker at the top of his gates of hell in a maze of figures. That might have been optimistic for the katascopos, even if the creator does not even have the place of the thinker. What I am attempting to essay is to present perspectives without one that brings everything into one stable focus, like the kaleidoscopes we turned into a pattern as children. The points of view of the reader will bring a new perspective to the interpretation of cultures.

Culture and interpretation are something that seep into us from all directions from an early age. Over the years, I have tried to acknowledge some of those who have helped me along the way, and I still wish to thank those I have in earlier books. Here, I would especially like to remember the course of Northrop Frye and Jay Macpherson I audited all those years ago on the Bible and mythology, showing how slow I can be to bring something to fruition. My thanks to Terence Cave, who was a Distinguished Visitor at Alberta, and shared with me his fine work on recognition and other topics. To Ross Chambers, another Distinguished Visitor to Alberta, many thanks for his suggestive ideas on culture and interpretation and for his inspiring example.

More generally, I would like to thank my schoolteachers who taught me many subjects, including literature, history, and geography, in English and French, and, above all, to John Bickell, who pursued the study of Canadian literature in the classroom when it was not the fashion. My thanks also to Timothy Findley, Robertson Davies, and others who encouraged my own poetry decades ago now. As a student, I was once at a meeting at University of Toronto where Robertson Davies felt obliged to come to defend Canadian literature as part of the curriculum. It was also a pleasure to audit classes given by Marshall McLuhan, who included Canada in his global village, and, with his permission, to read his Ph.D. thesis. My study places Canada in a multilateral context, especially, but not exclusively, in the Atlantic world, but also a temporal 
space that is related to a biblical and classical milieu and to European culture. My thanks to Doug Cole, Bill Byrick, and others at Sainte-Marieamong-the-Hurons, where I worked during the 1970s in various roles, including staff supervisor (although we also dressed up as French carpenters, blacksmiths, and Jesuits - much to the amusement of actual Jesuits who visited this historic site), for allowing me, even during the summer months, the privilege to pursue this history of encounter between the French and the Ouendat, and to reconsider and reinterpret the battle with European diseases and the final destructive war with the Iroquois in the 1640s.

This book was written over a long period. It often takes others to encourage, respond, and help to shape ideas. At Toronto, I learned much from many, but in particular I wish to thank Michael Sidnell who was exemplary in his teaching of modern drama and to Brian Parker, who with as much wit as wisdom led me into the ways of American drama and encouraged my interest in Shakespearean and other forms of drama. At Harvard, Daniel Aaron, Alfred and Sally Alcorn, G. Blakemore Evans, Marjorie Garber, Stratis Haviaris, Seamus Heaney, Barbara Johnson, Harry Levin, Donald and Cathleen Pfister, and Jan Ziolkowski were especially inspiring and supportive. My thanks to Peter Burke and Anthony Pagden at Cambridge for their encouragement of my historical work on the Atlantic world. At Princeton, my particular thanks to Jeremy Adelman, Sandra Bermann, Anthony Grafton, Michèle Lamont, Dale Miller, Kenneth Mills, Nigel Smith, and Harold Shapiro for their support, along with others, of my interests in history and literature, and especially in Canadian culture in a wider context of the Americas, the Atlantic world, and elsewhere. At Alberta, Ronald Ayling, E.D. Blodgett, Patricia Clements, Patricia Demers, Milan Dimić, James Forrest, Michael LynnGeorge, Nicole Mallet, Juliet McMaster, Peter Meekison, Robert Merrett, Edward Mojżeko, Gordon Moyles, John Orrell, Winnie Thom, Robert Wilson, Linda Woodbridge, and others were welcoming and supportive in my first years there. My continued thanks to the University of Alberta for its long-standing and ongoing flexibility and support for my teaching and research. To the librarians at these four universities, where I have spent the most time of any universities, and at the British Library, the Bodleian, the Bibliothèque Nationale, the Archive d'Outre Mer, the John Carter Brown Library, and elsewhere, I reiterate my thanks to you, which I have set out in earlier books. To the curators of the exhibits I have seen in museums and galleries in North America, Asia, Australia, and Europe (too many to list), my gratitude.

To all those who have invited me to give related talks in various places in different parts of the world or have given me invitations to write 
essays or articles, my thanks. In particular, my thanks to the organizers and hosts of the conference on Philosophy and Literature at George Mason University, where I presented a brief paper on recognition (I decided not to publish this or the considerably longer work, which appears here for the first time in any form); to Balachandra Rajan and Elizabeth Sauer for inviting an earlier version of my essay on Canadian colonial history in context; to Klaus Martens and his colleagues at Universität des Saarlandes for inviting me to a splendid conference on poetry (including poetry readings) and an earlier form of the essay on Canadian women writers; to Charles Stang for providing an invitation for a briefer and earlier essay on T.E. Lawrence and the Shaws; to Dorothy Figuiera and colleagues at the International Comparative Literature Association for inviting me to wonderful executive meetingswhere I presented a brief paper on the topic, an earlier version of the essay on poetry in the age of technology, which has been revised here; to Michael Trussler and his colleagues for publishing my earlier essay on poetry and mythology (and to Christian Riegel for his interest in this essay); to David Boyd and Imre Salusinszky, at University of Newcastle in Australia, for inviting a different version of my essay on Northrop Frye as a writer and for publishing a version in their collection on Frye; to Philip McGuire for inviting me to write on television drama and to speak on it on a couple of occasions at Michigan State University, and, most germane here, on a production of Miller's Death of a Salesman, and to James M. Welsh and his fellow editors for their interest in and publication of an earlier version; to Nat Hardy and his coeditors for inviting an essay on Irish poetry and another review of Paul Muldoon; to Jüri Talvet for issuing an invitation for the keynote of a conference on the novel at Tartu and for publishing a previous form of this chapter. Any specific acknowledgments to these works may be found in the notes to each chapter. This book has involved revision, framing the "argument," and an extension and an extensive revision of the notes. In the rewriting, I have been searching with Ariadne for the thread in the labyrinth of interpretation and culture.

For those who have shown support and have taught me through example, I thank all of you, especially Anne Barton, Catherine Belsey, Jean Bessière Mary Baine Campbell, Nicholas Canny, Margaret Ferguson, Stephen Ferguson, Philip Ford, Thomas Healy, Shelagh Heffernan, Robert Kroetsch, Thomas McAlindon, Kenneth Mills, Steven Mobbs, Christopher Norris, Peter Sinclair, Irene Sywenky, Gordon Teskey, Pauline Thomas, and Michael Worton. I also wish to remember Thomas M. Greene and Edward Said, who led seminars in which I 
participated at the School of Criticism and Theory (SCT). Robert Stepto and Valerie Smith, also at SCT, helped to develop my interest in African culture in the Americas. Many thanks, too, to those who have been so supportive at Palgrave. More specifically, it has been once more a great pleasure to work with my editor, Farideh Koohi-Kamali, and her associates, Julia Cohen, Elizabeth Sabo and Lynne Vande Stouwe. At Newgen, I thank Maran Elancheran and his colleagues for their work on production. For permission to reproduce Roy Kiyooka's splendid painting, "Toronto Boarding House 1950," my thanks to Kiyo Kiyooka and the Kiyooka family, the Alberta Foundation of the Arts Collection (AFA), and Barbara Johnson of the AFA. Further thanks to Alan Brownoff for making me aware of that work. This painting suggests an urban landscape, with all its suddenness and transitoriness, that has come to dominate the industrialized world. It is of a boarding house in Toronto, a city in which I have spent a lot of time, but gestures beyond this locale.

Thanks to my parents, George and Jean, whose interest in art, drama, literature, history, and other subjects has been an example for me. They met playing in Macbeth, and my mother's painting and my father's writing keep inspiring me as they still create in their eighties and nineties. They continue to lead me to leads. To my brothers and sisters, Charles, Gwendolyn, Deborah, Alan, and Jennifer, my thanks and appreciation for continuing in this spirit. All their commitment to arts and creativity have been a delicate but exuberant gift. Finally, thanks to my wife, Mary Marshall, and our twins, James and Julia, who have been with me for so much of this journey and who inspire love and gratitude. For Julia in particular - she who loves language, drama, literature, and culture, this work is dedicated. Cyrano follows his own threads, imaginary and otherwise, as we all might, at best in the service of love. 